\title{
Clashing Masculinities: Amos Oz's Panther in the Basement
}

\author{
Can Bahadır Yüce \\ Indiana University, 1011 E 3rd St, Bloomington, IN 47405, cbyuce@indiana.edu, \\ orcid.org/oooo-ooo1-5904-8007.Email: cbyuce@indiana.edu
}

Received December 14, 2017; Revised March March 31, 2018; Accepted April 10, 2018; Published May o6, 2018.

\begin{abstract}
In Middle Eastern fiction, the East-West discourse has largely been discussed through gender representations. Amos Oz's 1998 novel Panther in the Basement follows this pattern by offering a complex portrayal of concurrent themes regarding the creation of the modern Middle East such as nation-building and empire. The novel narrates the friendship between a Jewish boy and a British soldier. The contrast between the boy's emerging manhood and the soldier's deficient masculinity suggests a reading of the tension between nationalism and colonialism through the realm of gender. The boy's manliness features represent the idealism of the emerging nation-state whereas the soldier's vulnerable masculinity represents declining imperial colonialism. The novel's presentation of "clashing masculinities" indicates that a variety of masculinities exist, instead of one type of masculinity. This paper explores how Panther in the Basement offers cultural criticism by deconstructing the conventional conceptualizations of gender.
\end{abstract}

Keywords: masculinity, nationalism, colonialism, cultural criticism, gender, Amos Oz, the New Man, Middle Eastern literature.

"We met as enemies."

Proffy, Panther in the Basement

\section{Introduction}

The East-West discourse has always been a prominent theme in Middle Eastern fiction. During the formation years of the novel as a genre in the Middle East, the encounter between the Orient and the Occident was largely discussed through the realm of gender and sexuality. As Edward Said (1985) noted, Western culture has imagined and depicted the Orient in sexualized terms: Orientalists of the classical age saw the Islamic world "as feminine, its riches as fertile, its main symbols the sensual woman, the harem, and the despotic -but curiously- ruler" (103). Writers from the Middle East, on the other hand, attempted to reverse this rhetoric by describing the West as feminine and exotic, in a manner which Al-Azm (1980) calls "Orientalism in reverse." Several novelists ${ }^{\mathrm{i}}$ used the Western-originated literary genre to challenge or respond to the dominance of the West. As latecomers to the genre of novel, which first aroused as a Western invention, a compromise between Western formal influence and local materials shaped their works (Moretti, 2013, p. 50). Thus, the East-West encounter remained as a major source of anxiety for Middle Eastern novelists. On the other hand, their perception of European culture through gendered terms influenced the cultural dynamics of the twentieth-century Middle East.

While the scholarship on Arabic, Persian, and Turkish literatures primarily focuses on the Orient-Occident dichotomy with reference to gender representations, Israeli fiction has generally

(c) AesthetixMS 2018. This Open Access article is published under a Creative Commons Attribution Non-Commercial 4.0 International License (http://creativecommons.org/licenses/by-nc/4.o/), which permits non-commercial re-use, distribution, and reproduction in any medium, provided the original work is properly cited. For citation use the DOI. For commercial re-use, please contact editor@rupkatha.com. 
been excluded from the scope of this kind of research. ${ }^{\text {ii }}$ Even Israeli literature's belonging to the category of Middle Eastern literatures has been questioned. ${ }^{\text {iii }}$ Nonetheless, several works of modern Israeli fiction can be analyzed in the context of the East-West rhetoric. Among them, Amos Oz's novel Panther in the Basement portrays concurrent themes regarding the creation of the modern Middle East such as nation-building, empire, and gender norms. Narrating the story of an extraordinary friendship between a Jewish boy and a British soldier during the mandate period, the novel provides ground to examine intercultural encounters, the emergence of nationalism, and the decline of imperial colonialism through representations of masculinity. This article aims to explore how these notions correspond to the conceptualizations of gender and how the novel employs different types of masculinities to convey cultural criticism.

\section{The Novel of A Little "Traitor"}

First published in 1994, Panter Ba-Martef was translated into English in 1998 as Panther in the Basement. Narrated in the first person from the eye of a boy, the novel initially gives the impression that it is written for the young adult audience. Yair Mazor (2002) argues that this is a deliberate choice by the author, since the novel is "a quarry that contains all of the ores, minerals, and building materials of Oz's other works." (p. 105) Panther in the Basement opens with a striking sentence: "I have been called a traitor many times in my life." (p. 1) In the very beginning, the author implies that the notion of treason will be the main theme of the narrative. Proffy, the twelve-year-old protagonist, begins his story by referring to the centrality of the notion of treason in his social environment: "One morning these words appeared on the wall of our house, painted in black letters, just under the kitchen window: PROFI BOGED SHAFEL, 'Proffy is a low-down traitor."' (p. 1) In Proffy's coming-of-age story, it gradually becomes clear that the concept of treason is linked to masculinity. Each major development in the plot corresponds to the boy's masculine anxiety. Proffy repeatedly asks himself whether he betrayed his country by befriending with a British officer. "But what is treachery really?" (p. 28) he inquires naïvely. His search for an answer to this question frames the novel's approach to masculinity and nationalism.

Panther in the Basement can be defined as a bildungsroman: the young protagonist discovers adulthood, nature of friendship, and sexual awakening during the last summer of the British rule in the Middle East in 1947. He plays with his friends, Ben Hur and Chita Reznik, all the time and dreams of saving the promised land from the British and Arabs with a so-called secret organization named FOD (Freedom or Death). While exploring their masculinity, the boys keep practicing maneuvers to be ready to repel a coordinated attack by the Arab army when the British leave. As Cynthia Enloe (2004) notes, "child soldiers" and "occupation authorities" are conventional ungendered terms that serve to hide the political workings of masculinity and femininity (p. 4). Amos Oz's novel reverses this conventional rhetoric to initiate a gender debate by portraying child soldiers as manly and occupation authorities as effeminized subjects. Thus, the narrative tension is constructed through contrasting gendered representations.

The pivotal event in the novel is Proffy's encounter with Sergeant Dunlop, a British soldier and an amateur philologist who learned Hebrew in his hometown, Canterbury. Besides "the language of the Prophets," Dunlop knows Latin and some Greek. After they get to know each other, Proffy and Dunlop decide to meet three or four times a week in a café as conversation partners to exchange language skills. While considering the conversation hours as "secret" meetings, Proffy begins to like Dunlop and realizes that the sergeant is a kind-hearted man who loves Jewish people and culture. Despite the fear of being labeled as a traitor, Proffy is confident that he is not one: "I betrayed no secrets to Stephen Dunlop. Not a single one, not even a little 
one. I didn't even tell him my name." (p. 31) However, the feeling of guilt, a prevailing Jewish theme, keeps haunting the boy. His self-thoughts reflect how the nationalistic determination places hostility in a child's mind: "Loving the enemy, Proffy, is worse than betraying secrets." (p. 69) Although all he does is reading the Bible with Dunlop and teaching him some modern Hebrew words, when his friends learn that Proffy is befriended with a "British persecutor," they decide to interrogate him at the FOD court and question his manliness. That is to say, in the eyes of the boys, gender identity is determined through the notion of treason.

\section{Clashing Masculinities}

The construction of masculinity occupies a central place in Proffy's coming of age. The narrator, as a grown man, years later evokes the lifelong effects of social expectations from a boy: "Even in my dreams I defeated enemies, and I continued dreaming of wars for several years after that summer." (p. 21) As Mazor (2002) points out, “[The protagonist's] treachery lies in having succumbed to those reprehensible social standards that glorify power, aggression, and rabid masculinity. Proffy feels that he has adopted and internalized those standards." (p. 99) It is important to note that military and combat culture powerfully shaped the norms of masculinity in Israeli Jewish youth (Kaplan, 2000, p. 127). Accordingly, in Panther in the Basement, the characteristics of manliness imposed by nationalist ideology are expressed through the representation of the protagonist's emerging masculine identity.

I argue that the significance of the novel, regarding the masculinity discourse, lies in its presentation of two contrasting male images. A boy's emerging manliness is portrayed as the opposite of a middle-aged British soldier's underdeveloped masculinity. Whereas Proffy is depicted as a flourishing manly male, Sergeant Dunlop is described as an effeminate man. The contrast between gendered representations of the two main characters in the novel provides ground to discuss nation and empire as culturally-loaded and gendered topics.

Sergeant Dunlop is a passive and childish man with feminine features. Even though he has a large body, he is a "pink-faced, spongelike" man who "blushes a lot," and "his legs seem pudgy and hairless, with little wrinkles like those you see on the limbs of a baby." (p. 31) In the eyes of the protagonist, Dunlop is a "clumsy, rather feeble" guy (p. 35). His hands look like cotton wool: Proffy feels ashamed when shaking them as though was being touched by a girl. In fact, Dunlop looks like a "rubber doll that had been inflated" than a real man (p. 41). Even his cap seems more authoritative and official than the sergeant himself. He is also effeminately shy; when Proffy asks him whether he had a wife or children, Dunlop turns red from cheeks to ears (p. 138). If Proffy praises him, his "childlike" eyes light up. Although Proffy likes Sergeant Dunlop, the boy attempts to stifle his feelings because "the enemy is an enemy" after all. The boy keeps reminding himself that he is "not a girl [emphasis added]." (p. 54)

The sergeant is identified with the declining colonialism of the British Empire: "He looked like a man who once lost something very precious, and now he can't remember what it was he lost." (p. 79) The trauma of the imperial decline is linked to Dunlop's insecure masculinity. He lacks toughness, a major masculine feature: whereas Proffy shows no mercy to the enemy to prove his toughness, Sergeant Dunlop is a soft-hearted man who feels sorry for the local Arabs, and remarks that they are the weaker side soon to become the new Jews (p. 129). The British soldier's vulnerability is articulated by not only the protagonist but several characters. For example, Dunlop's effeminacy is observed by a young girl, Yardena, who thinks that the sergeant is an inhibited man (p. 131). 
The manly features of the young protagonist who represents the new nation suggest a contrast with Dunlop's deficient manhood. I call this tension "clashing masculinities" in which opposite norms of masculinity are contested. While masculinity and femininity are "inherently relational concepts...in relation to each other, as a social demarcation and a cultural opposition" (Connell, 2005, p. 44), they may also be relational in themselves. As Bourdieu (2001) points out, manliness is "an eminently relational notion, constructed in front of and for other men" (p. 53). In Panther in the Basement, contrasting gender identities of Proffy and Sergeant Dunlop are employed to allegorize the tension between emerging nationalism and declining imperialism. The boy's manly courage is superior to the sergeant's fragile manhood while male identities of the two characters are defined in relation to each other. In this relational construction of masculinity, Panther in the Basement assesses manliness with respect to masculine features of the opposite male character. Presented in sharp dichotomies, manhood is a relational quality in the novel; heroes, either manly or effeminate, are employed to convey the author's moral message and cultural criticism.

Representations of secondary characters in the novel also show how gender discourse is constructed through polarized models. For example, the protagonist's father is a rational, principled, serious man, and a decent Zionist; his mother, on the other hand, is sentimental and passionate. The representation of the protagonist's parents highlights the polarization between the male and the female. This polarization is crucial in the context of masculinity debate, since "a culture which does not treat women and men as bearers of polarized character types, at least in principle, does not have a concept of masculinity." (Connell, 2005, p. 68)

The title of the novel also reveals a contrast: as Mazor (2002) suggests, panther evokes strength and natural force, while basement connotes confinement and restraint (p. 99). That is to say, Amos Oz's dichotomist approach shapes the whole narrative, but it can be best observed in representations of masculinity. While representatives of the new nation are portrayed as manly males, Western or immigrant men are always vulnerable and effeminized in the novel: Mr. Lazarus, an immigrant from Berlin who lives in the same building with Proffy's family, is depicted as a timid man lacking masculine qualities.

\section{Empire and Masculinity}

In gender studies, the relationship between empire and masculinity is an understudied topic. Many scholars pointed out the link between the two notions but fewer attempted to elaborate on it. As Sarah A. Kaiksow (2008) observes, while a comprehensive history of gender and nation in the context of empire has yet to be sufficiently worked out, there remains little doubt about the centrality of empire politics to modern notions of masculinity (p. 64). On the other hand, equating colonial constructions of masculinity in different historical and geographical contexts can be misleading. It is true that masculinity is a norm of the colonial discourse, but at the same time classifying is a norm of masculine power. For example, "British in India constructed different images of masculinity for different peoples under their rule, for instance, contrasting effeminate Bengalis with fierce Pathans and Sikhs." (Connell, 2005, p. 254) The negation of the imperial masculinity in Panther in the Basement can be read as a satire of the colonialist discourse.

Sergeant Dunlop is obviously a copy of the imperial adventure hero, a well-known image which was popularized by T. E. Lawrence (1888-1935), or Lawrence of Arabia, a British army officer who notoriously organized Arab tribes for a revolt against the Ottoman rule. In the course of time, Lawrence has become the prominent "secret Western hero" figure regarding the Middle 
East. His image with local Arab garments, linguistic skills, and intelligence tricks made him famous. As Dawson (1991) points out, Lawrence's colorful costumes functioned as signs of the exotic richness of teaming Eastern life, timeless and unchanging since Biblical times (p. 117). David Lean's epic movie Lawrence of Arabia (1962) made the Lawrence image even more popular. As Roper and Tosh (1991) note, in the early twentieth century the British Empire's symbolic role in affirming the values of masculinity "grew more important as Britain's material decline from its nineteenth-century apogee began to enter public consciousness." (p. 14) The Orientalized British masculinity which was shaped by the Lawrence legend remained as a dominant image for a long time.

Sergeant Dunlop, who lives in the Promised Land during the bygone days of British colonial power, indisputably evokes this legend as a belated adventure hero. The British-Western cultural narrative of masculinity and Lawrence of Arabia as one of its symbols contextualize the negation of Dunlop's manhood. The success of the British imperialism against the Ottomans offered an opportunity for the reconstitution of imperial masculinity (Kaiksow, 2008, p. 64). In this context, I argue that the popular legend of Lawrence of Arabia is the most appropriate image to challenge the imperial masculinity. Panther in the Basement indirectly depicts the fading of the Lawrence image. As in the Lawrence legend, Sergeant Dunlop's desire to become "Oriental" is obvious, and it is the reason he wants to learn Hebrew from a boy. While Dunlop attempts going native, his portrayal as a weak man reverses "one of the oldest of all British imperial fantasies: that of bestowing freedom on a colonized people by the exercise of imperial authority." (Dawson, 1991, p. 125) Sergeant Dunlop is not a genuine imperial adventure hero; unlike Lawrence, he does not have the privileged knowledge of the authentic culture. Thus, he needs to learn "language of the enemy" from a child. As Hamilton Carroll (2011) notes, civilizing, saving and liberating are prominent features of Western manhood (p. 64), but Dunlop lacks these essential manly qualities. Moreover, the sergeant is not the only British male character in the novel whose manliness is negated: the investigation officer approaches Proffy's father "like a polite schoolboy" with a "face reddening as though he had been reprimanded." (p. 110) In the narrator's eyes, British men are far from being real men.

\section{The Emergence of the New Man}

In Middle East studies, while the quest for the "New Woman" dominates the gender/modernity discussions, the "New Man" is a relatively recent topic. As Hoda Elsadda (2007) argues, "representations of the New Man have always been a subtext in representations of the New Woman." (p. 35) However, the image of New Man is an indispensable part of the nationalistic discourse and nation-state projects in the Middle East. In Panther in the Basement, the emerging Jewish nationalism is represented through the young protagonist's awakening masculinity. In contrast to the effeminacy attributed to the declining colonial power, the nascent nation-state is represented through the image of the New Man.

The young protagonist of the novel is a model of the emerging New Man ideal which is nourished by Jewish nationalist ideology. Given the fact that the nation is a gendered construct (McClintock 1995), it is not surprising that in the twentieth-century nationalist Hebrew literature, gendered representations of the new nation have been dominant. Most famously, in his 1951 work With His Own Hands: Elik's Story, Moshe Shamir depicted the new ideal male for the new (promised) land. The famous opening line of the novel reads: "Elik came from the sea." Attributing the motherhood to the sea, the New Man discourse in Elik's story implies a mythical domain by portraying the new type of male as a product of a miracle, a man without a past. 
While modern Hebrew literature produces its heroes since the 1920s, the New Man of the new nation has constantly been depicted with superior manly features. The New Man is a nativeborn hero who has never experienced diaspora. Equipped with the features of enlightenment, he leads the nation to prosperity. He is a savior who will sacrifice himself for his people. The New Man is an identity which is closely intertwined with that of the nation to the extent that it produces a "personalized image of the nation" (Hroch, 1996, p. 90).

Representations of the young protagonist in Amos Oz's novel fit this discourse. As Proffy says, "The parents hoped that we children would grow up to be a new kind of Jew, improved, broad-shouldered, fighters and tillers of the soil." (p. 18) In other words, every teenage boy's parents want their child to become an Elik. However, Panther in the Basement departs from the conventional New Man rhetoric. Proffy's story, in fact, parodies the masculine nationalist discourse and astutely criticizes the extreme nationalism that leads to toxic masculinity. Eventually, it turns out treason, as a concept, is employed to address the nationalistic self-image satirically. The author criticizes the nationalist rhetoric by parodying manliness and portraying the boy's masculine anxiety.

\section{Conclusion}

Manhood and womanhood are relationally constructed through social relations. As Henriksson and Häyrén (2016) point out, reading masculinity as constructed in relation to other masculinities produces a different result than reading it as constructed in relation to femininity (p. 20). This fact indicates that a variety of masculinities exist, instead of one type of masculinity. In this article, I discussed representations of two types of masculinities in Amos Oz's novel Panther in the Basement. The contrast between the young protagonist's emerging manhood and the British soldier's insecure masculinity provides ground to discuss nationalism, colonialism, and gender constructions. Masculine features represent the idealism of the emerging nation-state whereas vulnerable masculinity represents declining imperial colonialism. I examined contrasting representations of gender identities as "clashing masculinities." I argue that Amos Oz's employment of contrasting images of masculinity can be read as a criticism of both nationalist and colonialist cultural constructions. With a tongue-in-cheek approach, Panther in the Basement offers cultural criticism by rethinking the conventional conceptualizations of masculinity.

\section{Notes}

\footnotetext{
${ }^{\mathrm{i}}$ Most notably, the Ottoman Turkish author Ahmet Mithat Efendi (1844-1912) is described by Orhan Pamuk as the father of the genre called "East-West novel." See Ahmet Mithat Efendi, (2016). Felâtun Bey and Râkım Efendi: An Ottoman Novel, New York, NY: Syracuse University Press.

ii This negligence is a consequence of perceiving the Middle East as a solely Muslim region. On the other hand, it should not be overlooked that Hebrew literature, from the beginning of the twentieth century until the 1940s, was seen as an imported product in Israel (Shaked, 2008, p. 139).

iii As a relatively recent example, Reza Aslan (2010) did not include works of Israeli writers in his comprehensive anthology of modern Middle Eastern literature, Tablet $\mathcal{E}$ Pen. However, works from South Asian literatures were included in the anthology. This choice indicates that scholars tend to define "Middle
} 
Eastern literatures" with reference to language and religion, rather than geography. The majority of the scholars who focus on the East-West relationship exclude Israel from the image of the exotic Orient.

\section{References}

Ahmet Mithat Efendi. (2016). Felâtun Bey and Râkım Efendi: An Ottoman novel. (M. Levi \&

M. M. Ringer, Trans.) New York, NY: Syracuse University Press. (Original work published 1875)

Al-Azm, S. J. (1980). Orientalism and orientalism in reverse. Khamsin, 8, 5-26.

Aslan, R (Ed.). (2010). Tablet E pen. New York, NY: Knopf.

Bourdieu, P. (2001). Masculine domination. (R. Nice, Trans.). Stanford, CA: Stanford University Press. (Original work published 1998)

Carroll, H. (2011). Affirmative reaction: New formations of white masculinity. Durham, NC: Duke University Press.

Connell, R.W. (2005). Masculinities. Berkeley, CA: University of California Press.

Dawson, G. (1991). The blond bedouin: Lawrence of Arabia, imperial adventure and the

imagining of English-British masculinity. In Roper, M., \& Tosh, J. (Eds.). (1991). Manful assertions: Masculinities in Britain since 180o. London: Routledge.

Elsadda, H. (2007) . Imaging the 'New Man': Gender and nation in Arab literary narratives in the early twentieth century. Journal of Middle East Women's Studies, 3/2, 31-55.

Enloe, C. (2004). The curious feminist. Berkeley, CA: University of California Press.

Kaiksow, S. A. (2008). Subjectivity and imperial masculinity: A British soldier in Dhofar (1968-1970). Journal of Middle East Women's Studies, 4/2, 6o-8o.

Kaplan. D. (2000). The military as a second Bar Mitzvah: Combat service as initiation to Zionist masculinity. In Ghașūu, M., \& Sinclair-Webb, E. Imagined masculinities : male identity and culture in the modern Middle East. London: Saqi.

Mazor, Y. (2002). Somber lust: The art of Amos Oz. New York, NY: SUNY Press.

McClintock, A. (1995). Imperial leather: Race, gender, and sexuality in the colonial contest. London: Routledge.

Moretti, F. (2013). Distant reading. New York, NY: Verso.

Oz, A. (1998). Panther in the basement. New York, NY: Harcourt. (Original work published 1994)

Roper, M., \& Tosh, J. (Eds.). (1991). Manful assertions: Masculinities in Britain since 180o. London: Routledge.

Said, E. W. (1985). Orientalism reconsidered. Cultural Critique, 1, 89-2017.

Shaked, G. (2008). Modern Hebrew fiction. London: Toby Press.

Shamir, M. (1970). With his own hands. Jerusalem: Institute for the Translation of Hebrew Literature. 